\title{
Influence of Development Partnership on State-Ingo Relations in Kenya
}

\author{
Timothy Chemweno* \\ Kisii University
}

*Corresponding Author: Timothy Chemweno, Kisii University

\begin{abstract}
Despite the fact that international non-governmental organizations are playing a major role in development, questions have been raised on their operations, funding and more so their effectiveness in societies they operate in. This study therefore, sought to examine the extent to which development partnership has fostered state-INGO relationship through transformation of the lives of the beneficiaries. This study also employed descriptive survey design. A sample size of 83 beneficiaries was employed and purposive sampling and random sampling was employed to select the 83 beneficiaries. Data were analysed by both qualitative and quantitative techniques. It was found that development activities by International Non-Governmental Organizations have not led to improved relations between state and the INGOs although achievements have been made on food security and economic growth of the beneficiaries in the following ways; increased the income of beneficiaries, enable beneficiaries to have saving habits, beneficiaries of development activities of INGOs through training are able to be innovative in working, beneficiaries of development activities of INGOs who are employed earn income which raises their standard of living, enable beneficiaries to control their expenditures, enable beneficiaries to budget and be accountable and enabled beneficiaries to increase their wealth. The study recommended that International Non-Governmental Organizations should formulate policies to reduce challenges that hinder state-INGO relations in project implementation. There is need for INGOs to also lobby for friendly policies from different levels of governments and that food security development partnerships initiated by INGOs should be sustained to enable beneficiaries increase income through commercial agriculture.
\end{abstract}

\section{INTRODUCTION}

\subsection{Background of the Study}

Development partnership in developing countries are currently the preferred avenue through which development efforts is channeled. Such efforts include project and programs in the state and international Non-Governmental organizations (INGOs) play a significant role. In developing countries, partnership has been experienced in promotion of social and economic change in sectors such as food security, water supply, education and health. In Sierra Leone for instance, INGOs played a significant role in management of Ebola outbreak which claimed at least 3691 lives within eight months. In essence, the primary role of government in any given nation in the world is to provide essentials to her citizens which is not the case in most if not all developing countries. For example, during the Ebola crisis, Sierra Leone like many developing countries had a very vulnerable national health systems that lack sufficient resources. The World Health Organization (WHO, Geneva, Switzerland) recommends a minimum of one healthcare worker for every 439 individuals. However, Sierra Leone had 5319 people for one health worker. Furthermore, the national government spent very little money on essential health services. While the WHO suggested $\$ 86$ per person, the Sierra Leone government spent only \$14 (Yoon Ah Shin, Jungwon Yeo and Kyujin Jung, Art April 2018).

In Latin America, INGOs have historically functioned in opposition to the government, playing a crucial role in strengthening civil society (Drabek, 1987). Consequently, the INGO sector here emerges from a stronger and more radicalized body of civil society organisations in opposition to the authoritarian regimes across the region (Bebbington, 2005). In Mexico, for example, INGOs emerged from university-educated members of the middle class motivated by their desire for 'transformation from below' through a process of mobilisation and sensitisation with poor communities (Miraftab, 
1997). In this original form, community development was seen as a secondary goal, justified only on the basis of serving the higher goals of social change (Miraftab, 1997). These popular movements, have, over time, experienced fragmentation, weakening, and identity crisis (Miraftab, 1997).

The role and contributions of INGOs in advocacy and empowerment can hardly be felt, but we can look at their efforts along a broad spectrum. INGOs actively intervening in democracy-building and transforming state-societal relations, such as those emerging to mobilize and support radical social movements in the early 'INGO decade' in Latin America (Rose, 2011). Kenya is also home to a large number of INGOs, some of whom implement projects to help in community development. When an organization wants to operate in Kenya, it must first register with the NGO Coordination Board. The Board is an organization created by an Act of Parliament in 1990 specifically to register, coordinate, and monitor the work of INGOs operating in Kenya. The registration process involves filling in a registration form and submitting the form along with an application fee to the INGO Coordination Board. The wide-ranging work of international organizations and NGOs can be categorized in terms of the roles of implementer, catalyst, and partner (Lewis, 2007). Failure by INGOs to demonstrate openness and accountability has attracted suspicion by host country's agencies and by the local community, who feel that INGOs impose projects on them rather than carrying out consultations before the projects are implemented, hence leading to resistance and mistrust. This mistrust has contributed to unsustainability of a number of projects.

\subsection{Statement of the Problem}

International non-governmental organizations (INGOs) are major development actors influencing State-INGO relations, especially developing nations. Questions have, however, been raised on their operations, funding and more so their effectiveness in societies they operate in. Accountability challenges have also been cited as some of the issues affecting operations by INGOs and have often led to developing states associating their activities with international politics. A section of Kenyan leaders have in the past raised concerns that some INGOs were out to cause regime change in the country due to the failure of INGOs to exercise transparency in their financing and utilization of funds.

In Marakwet East sub-county, the partnership between the State and INGOs in promoting community projects has not contributed to cordial State-INGO relation. There are cases of competing interest and lack proper agreements in selection and funding of priority projects. State and non-state actors involved in implementation of INGO and State projects often clash over project prioritization and mistrust. It has been argued that the voluntary sector, which includes INGOs may be better placed to articulate development projects that improve lives of the needs of poor people in remote areas, to encourage the changes in attitudes and practices necessary to curtail discrimination, to identify and redress threats to the environment, and to nurture the productive capacity of the most vulnerable groups such as the disabled or the landless. (OECD 1988, Elliott 1987, Fernandez 1987, Garilao 1987). This study investigated the influence of development partnership on state - INGO relations in Kenya.

\subsection{Purpose of the Study}

This study sought to examine the extent to which development partnership has influenced state-INGO relationships In Kenya. Specifically, the study sought to:

$>$ Establish the influence of development partnership in food security on State - INGO relations

$>$ Evaluate the contribution of development partnership in women and youth empowerment on State - INGO relations

$>$ Assess the influence of development partnership in education and health on State-INGO relations

$>$ Assess the challenges of development partnerships in promoting State-INGO relations

\subsection{Significance of the Study.}

The findings of this study are important in a number of ways. First, the findings will help development stakeholders understand the relationship between government and International NonGovernmental Organizations operating within the country, hence inform future relations between the Government and INGOs as well as stakeholders (comprising of individuals or countries) funding the INGOs. Secondly, the study will also provide an avenue for further academic research in the relationships between INGOs, communities and the government. 
Thirdly, the study will inform on the socio-economic impact of INGOs hence acting as a guidance tool for distribution and allocation of resources for sustainable community development. In addition, the community will also benefit from the study findings by being aware of the INGOs activities so that they can benefit from them. From the study findings, policies to regulate the INGO activities will be formulated hence eliminate double funding on projects implemented by both government and INGOs, which will in turn foster coordination and improve relations. Further, the findings of the study will form basis for formulation of policies that will help in the improvement of INGO activities and their relationship with the government and other development stakeholders and other countries.

\subsection{Scope of the Study}

The study was conducted in Marakwet East Sub County, Kenya. It focused mainly on basic sectors that have experienced development partnerships from both State and INGOs. Food security is one of those sectors that have received massive supports from both actors hence the need to establish the influence of development partners in food security on state-INGO relations.

\section{LITERATURE REVIEW}

\subsection{The Concept of INGO}

The term INGO is described as a range of groups and organizations from watchdog activist groups and aid agencies whose objectives are geared towards fostering development and policy changes. Usually, INGOs are defined as organizations that pursue a public interest agenda, rather than commercial interests (Hall-Jones, 2006). Davies (2013) says whereas most of the international associations Of the 1830s were to prove short-lived, the British and Foreign Anti-Slavery Society established in 1839 has survived to the present day as the oldest international human rights organization, now Anti-Slavery International, and still working across all continents on earth, persuading states to stop slavery. Its significance, according to Davies, extends beyond this achievement. British anti-slavery sentiment was one factor underpinning Whitehall's failure to recognize the Confederacy in the 1860s, playing a part in the abolition of slavery in the US.

From the late 1980s, INGOs assumed a far greater role in development than previously. INGOs were first discovered and then celebrated by the international donor community as bringing fresh solutions to longstanding development problems characterized by inefficient government to government aid and ineffective development projects. With the subsequent effort to liberalize economies, INGOs came also to be seen as a cost-effective alternative to public sector service delivery, hence occasioning poor relation with states because they were seen as making unpopular moves. They initiated more lifechanging projects than states. In the post-Cold War era the international donor community began to advocate a new policy agenda of "good governance" which saw development outcomes as emerging from a balanced relationship between government, market, and third sector. Within this paradigm, INGOs also came to be seen as part of an emerging "civil society."

The new attention given to INGOs at this time brought large quantities of aid resources, efforts at building the capacity of INGOs to scale up their work, and led ultimately to important changes in mainstream development thinking and practice, including new ideas about participation, empowerment, gender, and a range of people centered approaches to poverty reduction work. For example, Cernea (1988: 8) argued that INGOs embodied "a philosophy that recognizes the centrality of people in development policies," and that along with some other factors gave them "comparative advantages" over government. But too much was expected of INGOs, which came to be seen in some quarters as a "quick fix" for development problems. This had led to a backlash against INGOs by the end of the 1990s, when the evidence began to suggest that INGOs had only partially lived up to these unrealistically high expectations. A global shift also took place among development donors towards new ways of working with developing country governments, using mechanisms such as "budget support" and "sector-wide approaches" (Lewis, 2007).

\subsubsection{State - INGO Relations}

The growth of INGOs poses a dilemma for the state. Should the public authorities encourage or discourage private institutional initiatives in rural development? On the one hand, organized voluntary activity promises to contribute to the improvement of living standards, a developmental goal to which governments are themselves publicly committed. At best, the delivery of INGO services to rural areas can reduce the weighty managerial and fiscal burden of providing services on a nationwide basis. In 
most African countries, rural extension services operate intermittently, if at all. Faced with inadequate budgetary resources, extension agencies lack the means to execute programs and to pay personnel on time. As a result, they encounter declining morale, staff defections, and a lack of organizational effectiveness. Under these circumstances, it would appear to be in the public interest for the state to encourage INGOs to serve in an auxiliary role. Indeed, political leaders might stand to gain if INGOs can mobilize resources and deliver benefits to regions and communities that are otherwise unreachable (Michael, 1989).

The issue of government-INGO relations therefore raises fundamental questions about the balance between the state and civil society in Africa. In the West, voluntary associations played a formative role, not only in the accumulation of wealth, but as a crucible for forging an attachment to basic democratic values among the populace at large. Informed and active citizens, organized into autonomous associations and representative bodies, provided a counterweight to the accumulation of excessive power by a political executive. In Africa, however, the sequence of institution building has departed from this checked and balanced model. Political independence saw the intact transfer of an already large ("overdeveloped") state from colonial to nationalist hands. Political leaders used the power of this state to attempt to weld together the ethnically varied peoples within their boundaries into some semblance of nationhood.

The size and severity of challenges in each country of developing nation is different and, in most countries, governments desire to control all activities of INGOs. Therefore, it is not surprising that there are many quasigovernmental INGO in some developing countries, based on the governing regime. One of the most important issues ahead INGOs is "the decision-making processes." Tensions often occurred between staff and senior managers because of the staff expectations that they would be equal partners in the decision-making process. Another common problem is the governance of the organizations and the internal relations between board members and staffs (Mukasa, 2002).

\subsubsection{Development Partnership in Food Security and Health on State-INGO Relations}

In recent years, INGOs role and significance has increased in most developing countries and although they are often identified with powerless groups, they have become powerful and influential, especially because of their external sources of financial support, cooperation and advocacy, hence complimenting the state in its mandate to promote food security. They are estimated to have impacted on more than 250 million people with their diverse agendas and interest groups (Haque, 2002; Wies and Gordenker, 1996).

Over the last decade, INGOs especially those in Kenya, have presumably become prominent actors in the improvement of farming and livestock production. From relative obscurity a decade ago, they are now recognized and respected internationally. Donor governments and multilateral institutions now highly regard them due to their presumed capacity to reach the poor and the innovation flexibility which should characterize their work (Brodhead, 1987). As Vittorio Masoni states, they are now seen by official donors as more efficient than other often discredited official agencies (Masoni, 1985).

INGOs in the new millennium are more noticed and acknowledged due to their widespread presence in the development landscape and portrayed as a sizeable and dynamic component of a wide spectrum of societies throughout the world and especially in Africa (Tandon, 2000; Salomon et al, 1999). They gave a new perspective to development which looked at development from the base with local agendas and priorities, creating space for improving people's socio-economic situation.

Today, many INGOs in Africa are perceived as providing certain goods and services because they have gained technical expertise and experience by working in difficult settings or underserved populations and presumably tend to enjoy greater public trust than their government counterparts, thanks to their social welfare ideals (Teegen et al, 2004). These INGOs are mainly interested in community building and empowering the poor and they rely on procedures that are democratic, decentralized, and based on cooperation rather than competition. They are as assumed, located closer to the poor and care for them more than the state and are more aware of the particularities of local resources and constraints, making them more innovative, transparent, accountable and more effective, gaining them legitimacy (Sanyal, 1997).

\subsection{INGOs Activities and Influence on State Relations}

INGOs play an important role in global social development work that has helped facilitate achievements in human development as measured by the UN Human Development Index (HDI). One 
of the major strengths of INGOs is their ability to maintain institutional independence and political neutrality. Even though INGOs need to collaborate with governments in numerous instances, failure to maintain neutrality and autonomy may severely compromise the INGOs' legitimacy. Unfortunately, if a government insists upon political allegiance, the INGOs encounter the dilemma of either violating the neutrality position or failing to provide needed services to the population. Indeed, some INGOs have been asked to leave in troubled countries due to political reasons (Asamoah, 2003).

The major advantages that INGOs bring to this role include "flexibility, ability to innovate, grassroots orientation, humanitarian versus commercial goal orientation, non-profit status, dedication and commitment, and recruitment philosophy" (Asamoah, 2003). The drawbacks in working with INGOs are similar to the advantages that were previously listed. In addition, some other disadvantages include "over-zealousness, restricted local participation, inadequate feasibility studies, conflicts or misunderstandings with host partner, inflexibility in recruitment and procedures, turf wars, inadequately trained personnel, lack of funding to complete projects, lack of transparency, inability to replicate results, and cultural insensitivity" (Asamoah, 2003).

INGOs promote sustainable community development. Due to their particular ideology and nature, INGOs are good at reaching out to the poor and remote communities and mobilizing these populations. They can also empower these populations to regain control of their lives and can work with and strengthen local organizations. In addition, such INGOs can carry out projects more efficiently and at lower costs than government agencies and, most importantly, promote sustainable development (Nikkhah and Redzuan, 2010).

INGOs have played a significant role in promoting sustainable development at the international level. INGOs are going beyond their primary focus on governments and starting to address large corporations. In this vein, INGOs have focused attention on the social and environmental impacts of business activity, helped in part by advances in information and communications technology. The brands of multinational corporations have also been vulnerable to pressure from activists and from INGOs on the corporation's labor, environmental, or human rights record. As the downstream customers are targeted, even the supply chain partners and suppliers are feeling the pressure (HallJones, 2006).

INGOs can take most of the credit for creating these trends. The question remains as to how the business world should react to INGOs in the future. Should companies gear themselves in preparation of attacks from hostile critics? Should companies engage INGOs to become helpful partners? Depending upon their philosophy, not all INGOs are willing to collaborate with the private sector. Some of INGOs observe at a distance, and monitor, publicize, and criticize cases where companies fail to consider its impacts upon the community. However, other INGOs are willing to allocate some of their resources to working along with business in order to further corporate social responsibility (CSR) (Hall-Jones, 2006).

\subsection{Theoretical Framework}

This study was guided by the theory of Voluntary Failure by Salamon (2001), the theory merges aspects of the theory of public goods and theory of organizations. Organizational theory, which includes the theories of the firm and transaction cost, explains why it would be more efficient for private INGOs to deliver public goods rather than government. The theory of collective action and the free rider problem illuminate why government intervention is necessary to insure financial sustainability of NGOs.

The capabilities of NGOs place them in a better position to be solely responsible to execute programmes that drive development and alleviate poverty (Todaro \& Smith, 2008). As an organizational form, their closeness to communities helps to mobilize the kind of social action and sense of obligation needed to deal with problems of the really poor (Salamon, 1987). When INGOs function optimally they allow governments to promote welfare without an increase in government's administrative responsibilities (Zaidi, 1999).

This study utilizes this theory, to show how the government has allowed INGOs to operate in Tot Division. Health right International, World Vision and Red Cross, engage in many development activities to compliment the National Government. Despite the government, allowing INGOs to operate, it often intervenes to ensure that the strengths of both institutions are collaborated 


\subsection{Empirical Review}

In a study by Hibbard \& Tang (2004), a case study in Vietnam, illustrates that NGOs play an important role in promoting sustainable community development. Usually this is accomplished by providing three basic functions: (1) service delivery (relief, welfare), (2) education, and (3) public policy advocacy. This study did not highlight the specific activities undertaken by INGOs for socioeconomic development but rather sought to fill the gap on development partnership that influence State-INGO relations in Kenya.

In another study by Nikkhah and Redzuan (2010), established that the idea is that NGOs can promote sustainable community development via three functions: (1) microfinance, (2) capacity building, and (3) self-reliance. NGOs ought to develop local products and local markets; develop social, capital, and human resources; encourage and motivate people to participate in activities; and act as network liaisons between community and systems. In this manner, the long-run goal of sustainable community development would be achieved. Though the study highlighted microfinance as an economic aspect of INGOs it failed to explain in details how INGOs activities have influenced economic conditions of the beneficiaries. Therefore, this study sought to fill the gap by assessing how development activities by International Non-Governmental Organizations have affected the economic conditions of the beneficiaries in Tot Division.

\section{RESEARCH METHODOLOGY}

\subsection{Research Design}

A descriptive survey was the most appropriate for this study because in the study, the researcher collected information on the factors contributing to lack of adequate relationship between INGOs, beneficiaries and the government in implementation of projects in Marakwet East. Descriptive design was used to provide an opportunity for determination of relationship between variables in the selected International Non-Governmental Organizations and the development to beneficiaries.

\subsection{Target Population}

The target population were individual beneficiaries of developments projects for the five years of the selected INGO in Tot Division. In total, 2150 beneficiaries of INGO and state activities were included and the organizations were; World Vision and Red Cross.

Table3.1. Target Population

\begin{tabular}{|l|l|}
\hline Beneficiaries & Target population \\
\hline World Vision Beneficiaries & 900 \\
\hline Red Cross beneficiaries & 650 \\
Officers from Ministry of Interior and Coordination of National Government & 600 \\
\hline Total & $\mathbf{2 1 5 0}$ \\
\hline
\end{tabular}

\subsection{Sample Size and Sampling Procedure}

Kothari, (2004) defined a sample design as a definite plan for obtaining a sample from the sampling frame. Sampling design of $10 \%$ determined before any data is collected (Sekaran, 2006). Thus, the study sample size is 215 beneficiaries. The population is selected through simple random and purposive sampling techniques.

Table3.2. Sample Framework

\begin{tabular}{|l|l|l|}
\hline Beneficiaries & Target population & Sample Population 10\% \\
\hline World Vision Beneficiaries & 900 & 90 \\
\hline Red Cross beneficiaries & 650 & 65 \\
$\begin{array}{l}\text { Officers from Ministry of Interior and Coordination of } \\
\text { National Government }\end{array}$ & 600 & 60 \\
\hline Total & $\mathbf{2 1 5 0}$ & $\mathbf{2 1 5}$ \\
\hline
\end{tabular}

\subsection{Research Instruments}

\subsubsection{Questionnaire}

The researcher used questionnaire as a data collection instrument. This is a collection of items to which a respondent is expected to react in writing. The designed questions or items in word format 
were distributed to the beneficiaries. This method collects a lot of information over a short period of time (Mugenda \& Mugenda, 2003). The researcher constructed closed and Open -ended questionnaires which were administered to the beneficiaries of INGOs activities. The instrument was suitable for the information needed could be easily described in writing and in a limited time.

\subsubsection{Interviews}

The study also employed the use of interviews as a method of collecting data. This method was specifically used for collecting information from INGOs officials. Structured and semi-structured interview questions were designed for this exercise. The reason for use of interviews is that they are easy to administer since the questions were prepared in advance.

\subsection{Data Collection Procedure}

The researcher developed a thesis over a period of about one month under the guidance of the supervisors got a letter from Kisii University, Marakwet East Sub County Officials where the research was conducted and a permit from the NACOSTI to undertake the research. After the approval, the researcher proceeded to collect data from the beneficiaries using questionnaires. The data was collected by the researcher to limit the cost of research. Questionnaires were distributed to the beneficiaries in advance, and then collected after five days to give the beneficiaries time to fill. The data was analyzed using descriptive statistics and information was presented in form of tables.

\subsection{Validity and Reliability of Research Instrument}

\subsubsection{Validity}

Validity of an instrument is the success of a scale in measuring what it sets out to measure so that differences in individual scores can be taken as representing true differences on the characteristics under study (Koul, 1992). Validity refers to an agreement among professionals that a scale logically appears to reflect accuracy of what it purports to measure (Kothari, 2003).

The questionnaires and the interview schedules were scrutinized for errors and omissions, ambiguity, legibility and relevance. The questionnaires' content, structure and sequence were then appropriately amended to remove any ambiguities and to enhance content validity. To determine the content validity of the questionnaire items, two research experts in Kisii University were used to examine them and their suggestions and comments will be used as a basis to modify the research items.

\subsubsection{Reliability}

Reliability refers to the consistency that an instrument demonstrates when applied repeatedly under similar conditions (Kerlinger, 2003). To check on reliability of the instrument, the questionnaires were pre-tested through a pilot study to ascertain their effectiveness in soliciting the information intended.

This was done by administering the same instruments twice to the same group of subjects not in the sample groups, and by waiting for a period of two weeks before administering the research instruments for the second time. Then the correlation coefficient of the scores from both tests was calculated using a Pearson's product moment formula in order to establish the extent to which the contents of the questionnaire are consistent in eliciting the same responses every time the instrument is administered. According to Orodho (2004), a correlation coefficient of about 0.8 should be considered high enough to judge the instrument as reliable for a study. The calculated value was 0.83 and hence the researcher considered the instruments reliable for data collection.

\subsection{Data Analysis}

Data was collected through the use of questionnaires then coded and entered into the Statistical Package for the Social Sciences (SPSS). The data was analyzed using descriptive statistics. All objectives were analysed quantitatively by use of questionnaires. The numerical data was collected and presented in text, table and chart forms. The purpose of descriptive statistics enabled the researcher to meaningfully describe the findings and give a summary of data (Mbwesa, 2006).

Frequencies and percentages obtained were used in interpreting the respondent's perception on issues raised in the collected data so as to answer the research questions. Interview schedule was analysed qualitatively. Kombo and Tromp (2007) further observe that descriptive approach is designed to 
obtain information concerning the current phenomenon and wherever possible to draw valid conclusions from facts discussed.

\section{STUdY FINDINGS}

\subsection{Development Partnership and State-INGO Relation}

This study sought to examine the influence of development partnership in food security on StateINGO relation. Considering that the area of study is a semiarid area which depends mostly on irrigation for food production, the researcher sort to know from the beneficiaries of INGOs whether, International Non-Governmental Organizations provided irrigation services, 115 of the Respondents who represent $(53.49 \%)$ of the beneficiaries strongly agreed. "Most of the irrigation project in this area were constructed or improved by INGO, the Tot-Kolowa irrigation projects was built by Red Cross through the Njaa marufuku Kenya programme.

The findings show that $34.88 \%$ of the respondents who agreed that INGOs provided irrigation services, did not think that INGOs were solely responsible. "To a large percentage, I can say INGOs have brought irrigation projects, however, government has also brought in some of this project" Beneficiary Y argued. Additionally, 20 of the respondents who represented $(9.30 \%)$ of the beneficiaries disagreed saying, most of the irrigation projects in the area were farrows that were built by their fore fathers with a few by government. "The open farrows in this area were built by our forefathers and government rehabilitated some of them when they break up. They few done by INGOs have since stalled and most of their tanks have broken up" Beneficiary K said.

As shown in table 4.1. It implies that, most of the beneficiaries strongly agreed that International NonGovernmental Organizations implement irrigation projects in the area. One of the major irrigation projects identified was the Tot irrigation scheme established by the Kenya Red Cross Society in 2015. It is however important to note that, whereas majority do agree that INGOs have participated in providing irrigation services, it is evident that the development relation between State and INGOs is not that good and in turn has affected the implementation and service delivery to the beneficiaries.

\subsubsection{Livestock Improvement}

The Researcher sought to know from the beneficiaries whether International Non-Governmental Organizations provide improved livestock breeds, 90 respondents who represent $(41.86 \%)$ of the beneficiaries strongly agreed, "most of our animals before the coming of these INGOs were of poor breed but now they are improved, thanks to INGOs like world vision" one of the respondents said.

50 respondents who represent $(23.36 \%)$ of the beneficiaries agreed that animal livestock breeds have been improved courtesy if INGOs and also through government programs. Another 50 respondents who represent $(23.36 \%)$ of the beneficiaries were of a different opinion. They strongly disagreed with the argument that INGOs participated in improving livestock in the area but instead argue that, the livestock breeds have been improved due to government programs within the area.

\subsubsection{Agricultural Training}

Agricultural training is an important issue for the beneficiaries and so the researcher sought to know whether, International Non- Governmental Organizations Provide agricultural training and empowerment of farmers. A total of $100(46.51 \%)$ of the beneficiaries strongly agreed that they have had trainings that have transformed their agricultural activities from INGOs. "We have had a series of seminars and field days organized by these INGOs and they have been very important for us." One of the respondents said.

The study findings show that $85(39.53 \%)$ although agreed that INGOs have played a key role in training them, the state has also been present in providing the same though minimally compared to INGOs hence affirming that development partnership between State and INGOs exist though marginally. The findings show that $15(6.98 \%)$ of beneficiaries did not agree that INGOs have provided Agricultural training but instead argue that it is mostly government through its ministries that provide the same. "The little we know in agriculture is as a result of government, although they do not do it often, at least they do it once in a while" one of the respondents said.

Another 15 (6.98\%) of beneficiary strongly disagreed. In fact, they argue that they have never had any agricultural training at all. "Which training? We just operate at the mercies of the creator and maybe 
what we learned from our ancestors" one of the respondents answered. As shown in table 4.1. It means that, most of the beneficiaries have the conviction that International Non- Governmental Organizations Provide training among local farmers. However, a minimal percentage are of a different opinion. It also shows that the state and INGOs have not complimented each other in implementing the said activity hence elements of mistrust and double resource allocation is present.

\subsubsection{Employment}

Employment is a sensitive issue in any developing state. Having that in mind, the researcher sought to understand whether, International Non-Governmental Organizations created employment opportunities through Agricultural activities. A total of 115 (53.49\%) of the beneficiaries were of a strong conviction that no employment opportunities were created by INGOs through Agricultural activities. "We have never had any employment opportunities created by Agricultural activities by INGOs, I think we are better off without them" one of the respondents said.

The findings show $37 \%$ of the beneficiaries also disagreed, arguing that although they were getting the trainings, no substantial change in employment opportunities through Agricultural activities was realized. A minimal number of 15 respondents who make $(6.98 \%)$ of the beneficiaries agreed that, employment opportunities through Agricultural activities have been realized. "With the coming of these INGOs, new species of fruits have been introduced and some nurseries have been introduced which are manned by our people" one respondent argued. It also showed that $5(2.33 \%)$ of beneficiaries also agreed with conviction that employment opportunities have been created through Agricultural activities by INGOs in the area citing value addition to mangoes which is being practiced by a number of groups in the area.

\subsubsection{Project Sustainability}

The findings show that $83(38.60 \%)$ of the beneficiaries had a contrary opinion. They strongly disagreed, arguing that most of the projects established by INGOs in the area stalled almost immediately after they were established. "Most INGO projects collapse within months of establishment, look at the Red Cross malty million project that was to facilitate the irrigation of over 800 acres of arable land in the boarder of Marakwet and Pokot, it is a forgotten story. The pipes have been washed away, so we are back to where we started" one of the beneficiaries explained.

Also, a total of 75 (34.88\%) of the beneficiaries disagreed saying majority of the projects by INGOs were not sustainable although there are a few which are struggling. Moreover, 45 (20.93\%) of the beneficiaries agreed that, although most of the projects have had challenges, they are sustainable. An argument shared by $12(5.59 \%)$ of the beneficiaries who strongly agreed that, projects established by INGOs are sustainable. "Before we had traditional animals but the emergence of INGOs we have improved breeds, which tells you the project was sustainable" one of the respondents argued.

As illustrated by the table 4.1, most of the respondents disagree with the argument that projects initiated by International Non-Governmental Organizations in the area are sustainable. Based on the response of the respondents, it indicates that the relation between State and INGOs is never cordial. Projects established by INGOs are never taken up by state Bodies hence forcing them to collapse. A good example is The Kenya Red Cross society irrigation project that collapsed six months after it was established.

Table4.1. Influence of Partnership in Food Security on State-INGO relection

\begin{tabular}{|l|l|l|l|l|l|}
\hline Statement & $\begin{array}{l}\text { SA-5 } \\
\text { (Strongly } \\
\text { Agree) }\end{array}$ & $\begin{array}{l}\text { A-4 } \\
\text { (Agree) }\end{array}$ & $\begin{array}{l}\text { N-3 } \\
\text { (Neutral) }\end{array}$ & $\begin{array}{l}\text { D-2 } \\
\text { (Disagree) }\end{array}$ & $\begin{array}{l}\text { SD-1 } \\
\text { (Strongly } \\
\text { Disagree) }\end{array}$ \\
\hline $\begin{array}{l}\text { International non- } \\
\text { governmental } \\
\text { organizations provide } \\
\text { irrigation services. }\end{array}$ & $115(53.49 \%)$ & $75(34.88 \%)$ & & $20(9.30 \%)$ & $5(2.33 \%)$ \\
\hline $\begin{array}{l}\text { International non- } \\
\text { governmental } \\
\text { organizations help in } \\
\text { improved livestock } \\
\text { breeds. }\end{array}$ & $50(41.86 \%)$ & $50(23.36 \%)$ & & $25(11.63 \%)$ & $50(23.26 \%)$ \\
\hline
\end{tabular}




\begin{tabular}{|c|c|c|c|c|}
\hline $\begin{array}{l}\text { International non- } \\
\text { governmental } \\
\text { organizations provide } \\
\text { farmer training. }\end{array}$ & $100(46.51 \%)$ & $85(39.53 \%)$ & $15(6.98 \%)$ & $15(6.98 \%)$ \\
\hline $\begin{array}{l}\text { International non- } \\
\text { governmental } \\
\text { organizations create } \\
\text { employment } \\
\text { opportunities }\end{array}$ & $5(2.33 \%)$ & $15(6.98 \%)$ & $80(37.21)$ & $115(53.49 \%)$ \\
\hline $\begin{array}{l}\text { International non- } \\
\text { governmental } \\
\text { organizations projects } \\
\text { are sustainable. } \\
\text { Development projects } \\
\text { by INGOs have } \\
\text { fostered relations } \\
\text { with the state }\end{array}$ & $\begin{array}{l}12(5.59 \%) \\
50(23.30 \%)\end{array}$ & $\begin{array}{l}45(20.93 \%) \\
25(11.63 \%)\end{array}$ & $\begin{array}{l}75(34.88 \%) \\
90(41.86 \%)\end{array}$ & $\begin{array}{l}83(38.60 \%) \\
50(23.26 \%)\end{array}$ \\
\hline & & & & \\
\hline
\end{tabular}

Source: Researcher's Findings (2017)

On average, $46.78 \%$ of the respondents in this study strongly agree that development partnership in food security by State-INGO relations have had positive impact on the beneficiaries. Respondents however disagreed that the projects are sustainable. 83(38.60\%) of the respondents strongly disagreed that the projects are sustainable while $12(5.59 \%)$ disagreed. This was an indication that most of the projects have not been sustained to benefit the beneficiaries. $28.11 \%$, on average, agreed with the INGOs offered the above activities. $13.95 \%$ and $11.17 \%$ disagree and strongly disagreed respectively.

The findings also indicated that, $(41.86 \%)$ of the respondents strongly disagree that development projects undertaken by INGOs have fostered relations between the state and the INGOs. More so, another $23.36 \%$ of respondents disagreed that the development activities have helped improve relations between the state and INGOs with a further $23.26 \%$ of the respondents strongly agreeing and another $11.63 \%$ of them agreeing respectively that state-INGO relations were improved through the projects.

The above findings concur with Kilby (2000), pointed out that INGOs and NGOs pursue a wide range of objectives (social and economic) through a variety of methods (direct action, funding, lobbying, and networking). Of course, each role is not confined to a single organization, since an INGO may engage in all three groups of activities at once, or it may shift its emphasis from one to the other over time or as contexts and opportunities change.

\subsection{Evaluating the Contribution of Development Partnership in Women and Youth Empowerment on State - INGO Relations}

The study sought to find out from the respondents who were beneficiaries of International NonGovernmental Organizations activities on how development partnership in women and youth empowerment have influenced State-International Non-Governmental Organizations relations.

\subsubsection{Income Generation}

The researcher sought to know from the beneficiaries whether, development activities by INGOs have increased the income of the beneficiaries. The findings show 85 (39.53\%) of the beneficiaries strongly disagreed, arguing that, the activities have not brought in any income. "Most of these INGOs have been coming and going but we have not experienced any change in our livelihoods, we struggle to put food on the table" one of the respondents said.

The study reports that $70(32.56 \%)$ of the beneficiaries although disagreed, added that INGOs brought in negligible income if any but the state have through its line ministries brought in projects that have translated into income generating activities, a case in point being a Mango subsidy project initiated by the county government where a farmer buys one mango and gets another one free. "Projects by International non-governmental organization have never translated into any substantial income generation activity but if any, then it is negligible" one of the respondent argued. 


\subsubsection{Saving Culture}

In the view of whether development activities by INGOs have motivated the beneficiaries to have a saving culture, 115 of the respondents who make (53.49\%) of the beneficiaries strongly disagreed. "I cannot say that INGOs helped me develop a saving culture but rather the hardships I undergo daily triggered a survival instinct in me and most people in this area. Everything is hard to come by so when you get a little, you have to make sure it lasts you a while" one of the respondents said. A total of $70(32.56 \%)$ although disagreed, added that INGOs may have thought them one or two things on saving but they played a very minimal in influencing their saving culture.

In addition, $20(9.30 \%)$ of the beneficiaries agreed that, to a larger percentage, INGOs have instilled in the saving cultures. The study reports that $10(4.65 \%)$ of the beneficiaries strongly agreed. "We used not to save before the INGOs came in, we were doing the hand to mouth which meant we were ling a day at a go and the following day took care of itself" one of the respondents explained.

As illustrated in table 4.2, this means that, most of the beneficiaries have a strong conviction that, development activities by INGOs have played a minimal role motivating the beneficiaries to have saving culture. More so, development partnerships influencing State-INGOs relation proved elusive in this case. The state and INGOs have operated separately hence lacking coherence in service delivery that translates to development among the beneficiaries.

\subsubsection{Innovativeness}

In regard to whether beneficiaries of the development activities of INGOs, through training are able to be innovative in working, majority those 135 respondents who make $(62.79 \%)$ of the beneficiaries strongly agreed. "The different seminars and field days by INGOs have been an eye opener to most of us, at least some people have started value addition projects example mango juice and banana creeps which was unheard of before" one of the respondents elaborated.

Some of the respondents strongly disagreed, arguing that, Government has been supportive and in most cases it has trained the beneficiaries through field days and extension works on how to be innovative. "The National and county governments have personnel in the ground who have played a key role in educating us. We have acquired skills and a lot of knowhow from them" one of the respondents explained. 10 other respondents who constitute $(4.65 \%)$ of the beneficiaries disagreed saying, government has played a major role in provoking innovation and the INGOs have had minimal impact on the same.

As illustrated in table 4.2, it implies that most of the beneficiaries strongly agreed that beneficiaries of development partnership activities of INGOs through training are able to be innovative in working. It is also evident that development partnership that influence State-INGO relation is not cordial.

\subsubsection{Budgetary}

When the beneficiaries were asked whether beneficiaries of development activities of INGOs who are employed earn income which raises their standard of living. Majority 110(51.16\%) of the beneficiaries strongly agreed, "we have definitely had an improved lifestyle which in turn has transformed our individual lives and those of our families" one of the respondents said. 40 others who make $(18.60 \%)$ of the beneficiaries also agreed, arguing that, their lives have changed for the better after they started earning a salary.

A total of $40(18.60 \%)$ of the beneficiaries had a divergent opinion, they argued that government is a better employer and those employed by government have and income which has transformed their lives. In their observation, the impact brought in by salaries earned through the activities by INGOs on their lives is minimal. Another 20 (9.30\%) strongly disagreed arguing that, salaries earned through activities by INGO have not improved on their living standards at all. Nothing has changed in most of our lives even with the income we get through the activities by INGOs.

Also, $5(2.33 \%)$ of them were neutral as shown in table 4.2 and this shows that, although most of the beneficiaries strongly agreed that beneficiaries of development activities of INGOs who are employed earn income which raises their standard of living, there are those that say more is needed from the INGOs and state for transformation to be realized.

\subsubsection{Entrepreneurship and Wealth Creation}

In regard to whether development activities by INGOs have enable beneficiaries have the capacity create wealth, start and ran businesses. 130 respondents who form $(60.47 \%)$ of the beneficiaries 
strongly agreed, "the activities by INGO have been an eye opener for many, a number of people have seen an opportunity to start businesses which in turn have helped them accumulate wealth" one of the respondents elaborated

70other respondents who make $(32.56 \%)$ of the respondents also agreed saying, a majority of beneficiaries have been able to start businesses and accumulate wealth through development activities by INGOs but also, there are a few who have done so through development activities by the state.

The study found that $10(4.65 \%)$ of the beneficiaries disagreed and another 5 of the respondents who make $(2.33 \%)$ of the beneficiaries also strongly disagreed arguing that, activities by INGOs have prayed a minimal role compared to the state in activities that led to creation of wealth and ability to start a ran a business. As illustrated in the table 4.2. This implies that most of the beneficiaries strongly agreed that development activities by INGOs have enable beneficiaries acquire entrepreneurial and wealth creation skills. The study also exposed the relation between the state and INGOs which according to the responses by the beneficiaries is not mutual.

\subsubsection{State INGO Relation}

In regard to whether development activities by INGOs have improved State-INGO relations, 8 of the respondents who make $(3.72 \%)$ of the beneficiaries strongly agreed and another 7 respondents who make $(3.26 \%)$ of the beneficiaries agreed arguing that the State and INGOs have had mutual relation in the area. A larger majority of 120 respondents who make $(55.81 \%)$ of the beneficiaries and another 80 respondents who make $(37.21 \%)$ disagreed and strongly disagreed respectively. One of the respondents said "The State and INGOs have never had a good relation, most state and INGOs personnel undertake their duties separately even when the said activities are similar"

Table4.2. Partnership in women and youth empowerment on State-INGO Relation

\begin{tabular}{|c|c|c|c|c|c|}
\hline Statement & $\begin{array}{l}\text { SA-5 } \\
\text { (Strongly } \\
\text { Agree) }\end{array}$ & $\begin{array}{l}\text { A-4 } \\
\text { (Agree) }\end{array}$ & $\begin{array}{l}\text { N-3 } \\
\text { (Neutral) }\end{array}$ & $\begin{array}{l}\text { D-2 } \\
\text { (Disagree) }\end{array}$ & $\begin{array}{l}\text { SD1(Strongly } \\
\text { Disagree }\end{array}$ \\
\hline $\begin{array}{l}\text { Development } \\
\text { partnership activities } \\
\text { by State-INGOs } \\
\text { have increased on } \\
\text { income }\end{array}$ & $20(9.30 \%)$ & $30(13.95 \%)$ & $0(0.0 \%)$ & $85(39.53 \%)$ & $70(32.56 \%)$ \\
\hline $\begin{array}{l}\text { Development } \\
\text { partnership activities } \\
\text { by State-INGOs } \\
\text { have improved } \\
\text { saving culture }\end{array}$ & $10(4.65 \%)$ & $20(9.30 \%)$ & $0(0.0 \%)$ & $70(32.56 \%)$ & $115(53.49 \%)$ \\
\hline $\begin{array}{l}\text { Development } \\
\text { partnership activities } \\
\text { By State-INGOs } \\
\text { have improved on } \\
\text { innovativeness. }\end{array}$ & $5(2.33 \%)$ & $50(23.26 \%)$ & $10(4.65 \%)$ & $135(62.79 \%)$ & $15(6.98 \%)$ \\
\hline $\begin{array}{l}\text { Developments } \\
\text { partnership activities } \\
\text { by State-INGOs } \\
\text { have led to } \\
\text { employment. }\end{array}$ & $110(51.16 \%)$ & $40(18.60 \%)$ & $5(2.33 \%)$ & $40(18.60)$ & $20(9.30 \%)$ \\
\hline $\begin{array}{l}\text { Development } \\
\text { partnership activities } \\
\text { by State-INGOs } \\
\text { improved on } \\
\text { Budgetary }\end{array}$ & $125(58.14 \%)$ & $60(27.91 \%)$ & $0(0.0 \%)$ & $15(6.98 \%)$ & $15(6.98 \%)$ \\
\hline $\begin{array}{l}\text { Development } \\
\text { Partnership activities } \\
\text { by State-INGOs } \\
\text { haver improved } \\
\text { entrepreneurship and } \\
\text { wealth reation } \\
\text { skills. }\end{array}$ & $130(60.47 \%)$ & $70(32.56 \%)$ & $0(0.0 \%)$ & $10(4.65 \%)$ & $5(2.33 \%)$ \\
\hline
\end{tabular}




\subsection{Development Partnership of State INGO in Health and Education}

The study sought to find out from the respondents who were beneficiaries of International NonGovernmental Organizations activities on how development partnership by the State and International Non-Governmental Organizations have affected the social conditions in health and education.

\subsubsection{Religious Teaching}

When the beneficiaries were asked whether development partnership activities of State-INGOs improve the social relations with others through religious teachings by international Nongovernmental organizations. The study found that $115(53.49 \%)$ of the beneficiaries strongly agreed, in addition, another 80respondents who make (37.21\%) of the beneficiaries also agreed, one respondent said "most of our cultural ways curtailed our development rate but with the emergence of religion, we have seen a lot of changes in all spires of life example women can now be elected to positions of power unlike before".

In addition, $20(9.30 \%)$ of the beneficiaries disagreed arguing that religion played a minimal role in improving the social relation among beneficiaries. As illustrated in the table 4.3, the study reports that majority of the beneficiaries strongly agreed that beneficiaries of development partnership activities of State-INGOs improve the social relations with others through religious teachings by international organizations.

\subsubsection{Acquiring of New Skills}

In the view to understand whether beneficiaries of development partnership activities of State-INGOs have been empowered to acquire new skills which they use to develop and improve their lives. The study findings show that $100(46.51 \%)$ of the beneficiaries agreed, "INGOs have instilled in us relevant skills that have shaped our day to day lives example on how to protect our mangoes from destructive insects, how to improve our production just to mention but a few." One of the respondents explained.

In addition, 85 (39.53\%) of the beneficiaries strongly agreed that development partnership activities played a key role in empowering beneficiaries into acquiring new skills arguing that State/INGOs relation have had a huge impact on their development instilling relevant skills on them. 25 of the respondents who form $(11.63 \%)$ of the beneficiaries disagreed with another 5 of the respondents who make $(2.33 \%)$ of the beneficiaries strongly disagreeing.

As shown in table 4.3. This implies that most of the beneficiaries agreed that beneficiaries of development partnership activities of State/INGOs have been empowered to acquire new skills which they use to develop and improve their lives.

\subsubsection{Education}

In regard to whether, development partnership activities by State/INGOs has enable beneficiaries to get education. 125 respondents who form $(58.14 \%)$ and a majority of the beneficiaries strongly agreed, 70 other respondents who form (32.56\%) also agreed, one of the respondents said "State/INGOs have transformed us by providing an enabling environment to learn and also by providing relevant materials that facilitate learning among members of the community"

15 respondents who represent $(6.98 \%)$ of the beneficiaries disagreed and another 5 respondents who represent $(2.33 \%)$ of them strongly disagreeing arguing that, INGOs are not key players in the education sector but the state is. "The government plays a very critical role in the educational sector, INGOs on the other hand are insignificant and their involvement is negligible" one of the respondents said. As illustrated in the table 4.3, this means that most of the beneficiaries strongly agreed that development partnership activities by State/INGOs enable beneficiaries to get education.

\subsubsection{Fighting Female Genital Mutilation (FGM)}

On whether development activities by INGOs enable beneficiaries to fight Female Genital mutilation (FGM) in their area, majority of the respondents 110 who represent $(51.16 \%)$ of the beneficiaries strongly agreed, "INGOs have been on the forefront in the fight against FGM which a common practice within this area. To large larger extend their efforts led to reduced numbers and rescue of FGM victims" one of the respondents said. 
Another 60 (27.90\%) of the beneficiaries also agreed, arguing that although development activities by INGOs have played a big role in the fight against FGM, the state has also played a role by putting in place laws to assist in the fight against the vice. A total of 30(13.95\%) of the beneficiaries disagreed while $15(6.98 \%)$ of them strongly disagreed as shown in table 4.3. This implies that most of the beneficiaries strongly agreed that development activities by INGOs enable beneficiaries to fight FGM in their area.

\subsubsection{Improved Health Services}

When the beneficiaries were asked whether, development activities by INGOs enable beneficiaries to get improved health services. 115respondents who represent $(53.49 \%)$ of the beneficiaries strongly agreed, "a number of INGOs like Health rights international have come up with programmes that have assisted us access improved health services, others have equipped our hospitals" one of the respondents said.

With regards to the role of INGO in health management, majority $45(20.93 \%)$ of the beneficiaries also agreed, saying INGOs have cheeped in especially in places government are struggling. 30 respondents who represent $(13.95 \%)$ of the beneficiaries strongly disagreed saying INGOs play a negligible role in improving health service for beneficiaries.

The study also show that $25(11.63 \%)$ of the beneficiaries also disagree arguing that, government plays a pivot in improving health services as oppose to INGOs. As illustrated in 4.3. It is evident that most of the beneficiaries strongly agreed that development activities by INGOs enable beneficiaries to get improved health services.

Table4.3. Development Partnership of State-International Non-Governmental Organizations on Health and Education

\begin{tabular}{|c|c|c|c|c|c|}
\hline Statement & $\begin{array}{l}\text { SA-5 } \\
\text { (Strongly } \\
\text { Agree) }\end{array}$ & $\begin{array}{l}\text { A-4 } \\
\text { (Agree) }\end{array}$ & $\begin{array}{l}\mathrm{N}-3 \\
\text { (Neutral) }\end{array}$ & $\begin{array}{l}\text { D-2 } \\
\text { (Disagree) }\end{array}$ & $\begin{array}{l}\text { SD-1 } \\
\text { (Strongly } \\
\text { Disagree) }\end{array}$ \\
\hline $\begin{array}{l}\text { Beneficiaries of } \\
\text { development activities of } \\
\text { State-INGOs improve the } \\
\text { social through religious } \\
\text { teachings by international } \\
\text { organizations. }\end{array}$ & $115(53.49 \%)$ & $80(37.21 \%)$ & $0(0.0 \%)$ & $20(9.30 \%)$ & \\
\hline $\begin{array}{l}\text { Beneficiaries } \\
\text { development activities of } \\
\text { INGOs on acquiring new } \\
\text { skills to improve their } \\
\text { lives. }\end{array}$ & $85(39.53 \%)$ & $100(46.51 \%)$ & $0(0.0 \%)$ & $25(11.63 \%)$ & $5(2.33 \%)$ \\
\hline 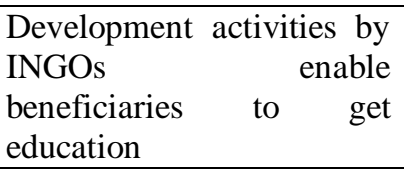 & $125(58.14 \%)$ & $70(32.56 \%)$ & $0(0.0 \%)$ & $15(6.98 \%)$ & $5(2.33 \%)$ \\
\hline $\begin{array}{l}\text { Development activities by } \\
\text { INGOs enable } \\
\text { beneficiaries fight FGM in } \\
\text { their area }\end{array}$ & $110(51.16 \%)$ & $60(27.90 \%)$ & $0(0.0 \%)$ & $30(13.95 \%)$ & $15(6.98 \%)$ \\
\hline $\begin{array}{l}\text { Development activities by } \\
\text { INGOs enable } \\
\text { beneficiaries to get } \\
\text { improved health services }\end{array}$ & $115(53.49 \%)$ & $45(20.93 \%)$ & $0(0.0 \%)$ & $25(11.63 \%)$ & $30(13.95 \%)$ \\
\hline
\end{tabular}

Source: Researcher's Findings (2017)

\subsection{State INGO Relations between Kenya and Other Countries}

The researcher sought to gather information on the influence of development and cooperation on relations between the state and the INGOs. He looked at INGO activities and how they have improved relations between Kenya and other countries, which are mainly the home countries of the INGOs. The researcher involved the respondents since they are the key recipients of the INGO socio economic projects. 
A likert Scale was used by the researcher to measure the attitudes of the beneficiaries and this was on a point 5 Scale (Strongly Agree, Agree, Not Sure, Disagree, and Strongly Disagree) where several statements were used to test the attitudes of the beneficiaries towards international relations. The researcher looked into the attitudes of the beneficiaries on the effects of INGO activities in the area on IR. Information concerning the respondents' attitudes is presented in Table 4.4.

Table4.4. State INGO relation between Kenya and other countries

\begin{tabular}{|l|l|l|l|l|l|}
\hline Statement & $\begin{array}{l}\text { SA-5 } \\
\text { (Strongly } \\
\text { Agree) }\end{array}$ & $\begin{array}{l}\text { A-4 } \\
\text { (Agree) }\end{array}$ & $\begin{array}{l}\text { N-3 } \\
\text { (Neutral) }\end{array}$ & $\begin{array}{l}\text { D-2 } \\
\text { (Disagree) }\end{array}$ & $\begin{array}{l}\text { SD1(Strongly } \\
\text { Disagree }\end{array}$ \\
\hline $\begin{array}{l}\text { INGOs home countries are } \\
\text { foreign }\end{array}$ & $85(39.53 \%)$ & $30(13.95 \%)$ & $0(0.0 \%)$ & $70(32.56 \%)$ & $20(92.30 \%)$ \\
\hline $\begin{array}{l}\text { INGOs have improved } \\
\text { relations between Kenya } \\
\text { and other nations }\end{array}$ & $70(32.56 \%)$ & $20(9.30 \%)$ & $0(0.0 \%)$ & $10(4.65 \%)$ & $115(53.49 \%)$ \\
\hline $\begin{array}{l}\text { Relation with other } \\
\text { countries through INGOs } \\
\text { have led to increased } \\
\text { funding for projects. }\end{array}$ & $135(62.79 \%)$ & $50(23.26 \%)$ & $5(2.33 \%)$ & $10(4.65 \%)$ & $15(6.98 \%)$ \\
\hline $\begin{array}{l}\text { Good relations with other } \\
\text { countries are achieved } \\
\text { through INGOs projects }\end{array}$ & & $60(27.91 \%)$ & $0(0.0 \%)$ & $15(6.98 \%)$ & $15(6.98 \%)$ \\
\hline
\end{tabular}

Source: Researcher's Findings (2017)

From the above table, a majority of respondents agree that most INGOs operating in the area have their origins in foreign countries. $39.53 \%$ and $13.95 \%$ of the beneficiaries strongly agree and agree respectively that a majority of the INGOs operate in multiple countries across the world. They identified Health right International and World Vision as the main INGOs operating in the area. On whether the INGOs have improved relations between Kenya and other nations, 32.5\% strongly agreed that inter-state relations have improved thanks to INGO activities. Another 9.35 agreed while $4.65 \%$ and $53.5 \%$ disagreed and strongly disagreed respectively.

$62.79 \%$ agreed that funds for INGO activities have increased due to improved relations between the state and foreign countries while $6.98 \%$ feel that the relations have not contributed to any increase in funds for INGO projects. A majority (27.91\%) of respondents agree that INGOs help to foster good relations among countries. 6.98\% disagreed with the relations among countries are achieved through INGO activities. Those in agreement cited USaid and UKaid as INGOs that have fostered between Kenya and United States and between Kenya and United Kingdom respectively.

\subsection{Challenges Facing State-INGO Relations in Implementation of Development Activities}

The study sought to find out from the respondents who were beneficiaries of International NonGovernmental Organizations activities on challenges facing International Non-Governmental Organizations as they implement their development activities.

Beneficiaries were asked whether some activities of international nongovernmental organizations and those of the government are the same resulting to conflicts. Majority of the respondents 135 (62.79\%) of the beneficiaries strongly agreed, "It is true that projects by INGO are similar to those by the government making it difficult to differentiate" one of the respondents said. Additionally, 70 other respondents who represent (32.56\%) also agreed, 15 (6.98\%) of the beneficiaries and another 5 $(2.33 \%)$ of the beneficiaries agreed and strongly disagreed respectively. As illustrated in table 4.5, this implies that most of the beneficiaries strongly agreed that international nongovernmental organizations and those of the government are the same resulting to conflicts.

\subsubsection{Budgetary Allocation and Effects to INGO Operations}

In the view of whether International non-governmental organizations inadequate budgetary resources affect their operations, 115 respondents who represent $(53.49 \%)$ a majority of the beneficiaries strongly agreed, 60 other respondents who represent $(27.91 \%)$ of the beneficiaries also agreed arguing that, resources are paramount to the success of any INGO.

The findings show that 20 (9.30\%) of the beneficiaries strongly disagreed arguing that, most INGOs do fail in their activities because of management issues. A further number of 15 respondents who 
represent $(6.98 \%)$ of the beneficiaries disagreed, "as much as inadequate budgetary allocation may play a role in affecting the operations of INGOs, management and lack of proper structure is the key issue on why the fail" one of the respondents argued. 5 respondents who represent $(2.33 \%)$ of the respondents were neutral as shown in table 4.5. This implies that most of the beneficiaries are of the impression that, International non-governmental organizations inadequate budgetary resources affect their operations.

\subsubsection{INGO Activities on State/INGO Relation}

In regard to whether some activities of international nongovernmental organizations initiatives may reflect unfavorably on the government's performance at inducing rural development. 125 of the respondents who represent $(58.14 \%)$ of the beneficiaries strongly agreed and another 50 respondents who represent $(23.26 \%)$ agreed, "INGOs have taken over a number of projects in this area that primarily were to be done by government and we are happy they were around to assist" one respondent explained. 22 respondents who represent (10.23\%) of the beneficiaries strongly disagreed. One of them argued "INGOs are doubling on activities that government has already done, I believe they do so with the sole intention of squandering money".

\subsubsection{Social and Cultural Issues on INGO Relations}

When the beneficiaries were asked whether cultural and social factors constrain their operations, majority $135(62.79 \%$ ) of the beneficiaries strongly agreed, 50(23.26\%) agreed, 15(6.98\%) strongly disagreed while $5(2.33 \%)$ of them were neutral as shown in table 4.3. This implies that most of the beneficiaries strongly agreed that cultural and social factors constrain their operations.

\subsubsection{Management/ Leadership Problems}

On whether many organizations suffered from management and leadership problems,130respondents who represent $(60.47 \%)$ of the beneficiaries strongly agreed, 70other respondents who make (32.56\%) also agreed, "it is sad to admit that most if not all INGOs have management and leadership problems" one of the respondents said. A total of 10 respondents who represent $(4.65 \%)$ of the beneficiaries strongly disagreed arguing that, most INGOs are more organized than government. Another 5 respondents who make (2.33\%) of the beneficiaries choose to be neutral as shown in table 4.5. This implies that, most of the beneficiaries strongly agreed that many organizations suffered from management and leadership problems.

When the INGOs officials were interviewed, most of them conquered with the beneficiaries. The argued that, International Non-Governmental Organizations are faced with a number of challenges especially when implementing their development activities. According to the officials, roles of international nongovernmental organizations and those of the government are the same hence resulting to conflicts? They also added that, inadequate budgetary allocation of resources affects the day to day operations of international nongovernmental organizations.

More so, INGO initiatives were also mentioned as some of the issue that bring about conflict between the State and INGO as they reflect unfavorably on the government's performance especially inducing rural development in areas which government is suspected to be performing dismally. The officials mentioned that, cultural and social factors have in most cases constrained their operations making it difficult for them to register maximum results. Management and leadership problems were also mentioned as some of the issues that curtail the success of most international Non-governmental organizations.

Table4.5. Challenges Facing State/ International Non-Governmental Organizations in Implementation of Development Activities

\begin{tabular}{|l|l|l|l|l|l|}
\hline Statement & $\begin{array}{l}\text { SA-5 } \\
\text { (Strongly } \\
\text { Agree) }\end{array}$ & $\begin{array}{l}\text { A-4 } \\
\text { (Agree) }\end{array}$ & $\begin{array}{l}\text { N-3 } \\
\text { (Neutral) }\end{array}$ & $\begin{array}{l}\text { D-2 } \\
\text { (Disagree) }\end{array}$ & $\begin{array}{l}\text { SD-1 } \\
\text { (Strongly } \\
\text { Disagree) }\end{array}$ \\
\hline $\begin{array}{l}\text { Development activities } \\
\text { of international } \\
\text { nongovernmental } \\
\text { organizations have } \\
\text { improved } \\
\text { relations with the state. }\end{array}$ & $5(2.33 \%)$ & $15(6.98 \%)$ & 0 & $135(62.79 \%)$ & $70(32.56 \%)$ \\
\hline
\end{tabular}




\begin{tabular}{|l|l|l|l|l|l|}
\hline $\begin{array}{l}\text { International non- } \\
\text { governmental } \\
\text { organizations } \\
\text { inadequate budgetary } \\
\text { resources affects their } \\
\text { operations }\end{array}$ & $115(53.49 \%)$ & $60(27.91 \%)$ & $5(2.33 \%)$ & $15(6.98 \%)$ & $20(9.30 \%)$ \\
\hline $\begin{array}{l}\text { Some activities of } \\
\text { international } \\
\text { nongovernmental } \\
\text { organizations } \\
\text { initiatives may reflect } \\
\text { unfavorably on the } \\
\text { government's at } \\
\text { performance rural } \\
\text { inducing and } \\
\text { development. }\end{array}$ & $50(23.26 \%)$ & $3(1.40 \%)$ & $15(6.98 \%)$ & $22(10.23 \%)$ \\
\hline $\begin{array}{l}\text { Cultural and social } \\
\text { factors constrain their } \\
\text { operations. }\end{array}$ & $135(62.79 \%)$ & $50(23.26 \%)$ & $5(2.33 \%)$ & $10(4.65 \%)$ & $15(6.98 \%)$ \\
\hline $\begin{array}{l}\text { Many organizations } \\
\text { suffered } \\
\text { management from } \\
\text { leadership problems. }\end{array}$ & $130(60.47 \%)$ & $70(32.56 \%)$ & & & \\
\hline
\end{tabular}

Source: Researcher's Findings (2017)

\section{SUMMARY, CONCLUSION AND RECOMMENDATION}

\subsection{Summary of Findings}

On average, $46.78 \%$ of the respondents in this study strongly agree that development partnership in food security by State-INGO relations have had a positive impact on the beneficiaries. They argue that, with the emergence of INGOs, the beneficiaries have been in a position to improve on their food security through a series of activities that include Irrigation, livestock improvement, agricultural training and employment just to mention a few which played a key role in making sure that the beneficiaries produce enough food hence be food secure.

The success of any given project in a state depends mostly on the commitment of the different partners/actors in sustaining it for a lengthy period of time. The Red Cross Irrigation project in Tot was meant to benefit two conflicting communities in Kenya's Kerio valley whose environment is hostile and lacks sufficient water supply. With an intention of understanding on the sustainability of the various INGO projects, the researcher sought to know from the beneficiaries whether projects established by International Non-Governmental Organizations are sustainable. The respondents disagreed on the sustainability of the said projects with $38.60 \%$ of the respondent strongly disagreeing and another $34.88 \%$ disagreeing respectively that the projects are sustainable.

The INGOs officials who were interviewed by the researcher agreed with most of the responses given by the beneficiaries. 60 per cent of them said that, development activities by INGOs have transformed the lives of the beneficiaries for the better. They however indicated that, a number of INGO development activities have lacked sustainability which they attributed to inadequate resources from the donors. More so, development partnership relation between the state and most INGOs is not cordial hence translating to mistrust, double funding and sabotage.

On the other hand, INGOs have majored on awareness and sensitization programmes which are aimed at empowering both Woman and Youth on the Utilization of funds that include those from government. The existence of gender related barriers like cultural belief and educational disparities among others have adverse effect on national development.

Some respondents agreed that activities by INGOs have generated income with $13.95 \%$ agreeing and 9.30\% strongly agreeing. This implies that most of the beneficiaries agreed that development activities by INGOs have not increased the income of beneficiaries in the area. The same also applied in whether INGO activities have motivated the beneficiaries to have a saving culture, $53.49 \%$ of the beneficiaries strongly disagreed. $32.56 \%$ although disagreed, added that INGOs may have thought them one or two things on saving but they played a very minimal in influencing their saving culture 
A small percentage of $9.30 \%$ of the beneficiary argued that INGOs have instilled in them saving culture with another $4.65 \%$ of the beneficiaries strongly agreeing. This means that, most of the beneficiaries have a strong conviction that, development activities by INGOs have played a minimal role in motivating the beneficiaries to have a saving culture. More so, development partnerships influencing State-INGOs relation proved elusive in this case. The state and INGOs have operated separately hence lacking coherence in service delivery which translates to development among the beneficiaries.

In regard to whether development activities by INGOs have improved State-INGO relations, 3.72\% of the beneficiaries strongly agreed and another $3.26 \%$ of the beneficiaries agreed arguing that the State and INGOs have had mutual relation in the area. A larger majority of $55.81 \%$ of the beneficiaries and another $37.21 \%$ disagreed and strongly disagreed respectively. Following the response by the respondents, It is evident that, the state- INGOs relation is never mutual hence their activities may not necessarily yield much compared to a situation where they complimented each other.

The same sentiments were shared by one of the INGO officers interviewed who argued that development activities by International Non-Governmental Organizations have affected the economic conditions of the beneficiaries in a number of ways which included; Education and health, women and youth empowerment, food security among others.

\subsection{Conclusion}

Based on the findings, the study concludes that partnership in food security and its influence on stateINGO relations include; INGOs have initiated projects aimed at improving agricultural activities in the study area including irrigation schemes and livestock improvement programmes, but have not been sustained to enable beneficiaries increase their income. The failure to sustain the development projects has not fostered state-INGO relations.

Paradigm shifts in livelihoods on state-INGO relations include; challenges facing International NonGovernmental Organizations as they implement their development activities include; roles international nongovernmental organizations and that of the government are the same resulting to conflicts, International non-governmental organizations inadequate budgetary resources affect their operations, international nongovernmental organizations initiatives may reflect unfavorably on the government's performance at inducing rural development, cultural and social factors constrain their operations and many organizations suffered from management and leadership problems.

Development activities by International Non-Governmental Organizations have affected the economic conditions of the beneficiaries in the following ways; increased the income of beneficiaries, enable beneficiaries to have saving habits, beneficiaries of development activities of INGOs through training are able to be innovative in working, beneficiaries of development activities of INGOs who are employed earn income which raises their standard of living, enable beneficiaries to control their expenditures, enable beneficiaries to budget and be accountable and enable beneficiaries to increase their wealth.

Development activities run by International Non-Governmental Organizations have affected the social conditions of the beneficiaries in the following ways; improve the social relations with others through religious teachings by international organizations, beneficiaries of development activities of INGOs have been empowered to form groups which they use to develop and improve their lives, enable beneficiaries to get education, enable beneficiaries to get security in their area and enable beneficiaries to get improved health services.

\subsection{Recommendation}

Based on the findings from the study, the researcher made a few recommendations that touched on food security and other key objectives on State-INGO relations. The agricultural activities initiated by INGOs should be sustained by the state to enable beneficiaries increase income through commercial agriculture. This will in turn foster the state-INGO relations.

More so, there is need for INGOs to involve beneficiaries in identification and implementation of projects to promote sustainability of the activities and bring a sense of ownership of the food security projects among beneficiaries. International Non-Governmental Organizations should diversify activities that benefit the community in order to satisfy their needs. This was informed by the fact that 
the study noted beneficiaries still suffer from acute shortages of water, leading to a shortage of food. It recommends that to close this gap, there is need for INGOs to educate locals on water conservation and utilization by use of modern pipes as oppose to the open farrows.

The study recommends that International Non-Governmental Organizations should formulate policies to reduce challenges that hinder state-INGO relations in project implementations. There is need for INGOs to also lobby for friendly policies from different levels of governments.

\subsection{Suggestions for Further Research}

Further study should be conducted on Policies used by both state-INGO in education and Health for better service delivery and improved State-INGO relations. In addition, further study should be carried out by both actors to determine how they can collaborate and complement each other without necessarily conflicting or rather overstepping set mandates.

\section{REFERENCES}

[1] Anheier, H.K. (2005). Nonprofit Organisations: Theory, Management and Policy. New York: Routlegde Press.

[2] Baccaro, L. (2001). Civil Society, NGOs, and Decent Work Policies: Sorting out the Issues: The Discussion Paper Series presents the preliminary results of research undertaken. IILS: Geneva.

[3] Bebbington, A. J. (2005). Donor-NGO relations and representations of livelihood in nongovernmental aid chains. World Development: 33(6): 937-950.

[4] Beauchamp, T. L. \& Bowie, N. E. (2004). Ethical theory and business (7th ed.). Upper Saddle River. NJ: Pearson Education.

[5] Black, P. Calitz, E. \& Steenkamp, T. (2008). Public Economics 4th Edition. Cape Town: Oxford University y Press.

[6] Boettke, P. J. \& Prychitko, D.L. (2004). Is an Independent Nonprofit Sector Prone to Failure? Toward an Austrian School Interpretation of Nonprofit and Voluntary Action. Conversations on Philanthropy: I: 1-40.

[7] Brahmi, M.K. \& Thakur, S (2011). Factors Affecting People Participation in Hariyali project under Nalagarh Block of Himachal Pradesh. Journal of $\quad$ Farm Sciences: $1 \quad$ (1). www.inflibet.ac.in accessed 20 July 2012.

[8] Brass, J. N. (2012). Why do NGOs go where they go? Evidence from Keny. World Development: 40(2): 387-401.

[9] Cerulli, G. (2006). The Redistributive Role of Non-profit Organizations. Munich Personal RePEc Archive: MPRA Paper No. 28.

[10] Collier, P. (2007). "Aid to the Rescue?" in The Bottom Billion: Why the Poorest Countries are Failing and What Can Be Done About It, pp. 99-123. Oxford and New York: Oxford University Press.

[11] Desai, V. (2005). NGOs, gender mainstreaming, and urban poor communities in Mumbai. Gender and Development, 13(2): 90-98.

[12] DFID. (Department for International Development), (1997). Eliminating world poverty: A challenge for the 21st century. London: The Stationery Office.

[13] Dollery, B. \& Wallis,J. (2001). Economic Approaches to the Voluntary Sector: A note on Voluntary Failure and Human service Delivery. Working Paper Series in Economics: No.2001-16-December.

[14] Dorsener, C. (2004). Social Exclusion and Participation in Community Development Projects: Evidence from Senegal. Social Policy and Administration: Volume 38, No.4.

[15] Ebrahim, A. (2003). Accountability in Practice: Mechanisms for NGOs', World Development

[16] Ferron, S. Morgan, J. O’Reilly, M. (2000). Hygiene Promotion - Practical Manual for Relief and Development. $1^{\text {st }}$ Edition. London: ITDG Publishing.

[17] Friedmann, J. (1992). Empowerment: The politics of alternative development. Oxford: Blackwell.

[18] Ghosh, S. (2009). 'NGOs as political institutions', Journal of Asian and African Studies 44: 475-495.

[19] Green, A. and Matthias, A. (1995). NGOs - A policy panacea for the next millennium. Journal of international Development. 7(3). pp. 565-73.

[20] Guijht, I. \& Shah, M. (1998). Waking Up to Power, Conflict and Process", in GuijhtI \& Shah (eds). The Myth of Community: Gender issues in Participatory Development. London: Intermediate Technology.

[21] Hall Jones, Peter. (2006). The Rise and Rise of NGOs in Public Services International.

[22] Haugen, Gary; Boutros, Victor (2010). "And Justice for All: Enforcing Human Rights for the World's Poor". Foreign Affairs. 89 (3): 51-62. 
[23] Jianxiu, G. (2006). The Role of NGOs in the Social Welfare. Canadian Social Science. 2(4):15-18.

[24] Kaimowitz, David. (1993). The Role of Nongovernmental Organizations in Agricultural Research and Technology Transfer in Latin America. World Development 21:1139-1150.

[25] Kerlinger, F. N. (2003). Foundation of behavioral science. New York: Holt, Rene hard and Winston.

[26] Kombo, D. K. and Tromp, D. L. A. (2007). Project and Thesis Writing: An Introduction. Pauline's Publications' Africa, Nairobi.

[27] Kotze, D.A. (ed). (1997). Development Administration and Management: A holistic Approach. Pretoria: Van Schaik.

[28] Koul, L. (1992). Methodology in Educational Research. Delhi: Vikas Publishing House, PVT Ltd.

[29] Langran L.V. (2002). Empowerment and the Limits of Change: NGOs and Health Decentralization in the Philippine, Department of Political Science. Ph.D. Thesis, Toronto: University of Toronto.

[30] Lewis, D. and N. Kanji, (2009). Non-Governmental Organizations and Development. Abingdon, UK: Routledge.

[31] Lewis, D. (2007). Management of nongovernmental development organizations. NGOs and development: Analysing NGO roles: Implementers, catalysts and partners. London: Routledge.

[32] Lewis, D. (2005). 'Actors, ideas and networks: trajectories of the non-governmental in development studies', in U. Kothari (ed.), A Radical History of Development Studies, London: Zed Books.

[33] McGann, J. and M. Johnstone. (2006). The Power Shift and the NGO Credibility Crisis. In The International Journal of Not-for-Profit Law Volume 8, Issue 2. International Center for Not-for-Profit Law: Washington, DC.

[34] Miller-Grandvaux, Y. Welmond, M. \& Wolf, J. (2002). Evolving Partnerships: The Role of NGOs in Basic Education in Africa. United States Agency for International Development. Bureau for Africa, Office of SustainableDevelopment: Washington DC.

[35] Miraftab, F. (1997). Flirting with the enemy: challenges faced by NGOs in development and empowerent. Habitat International: 21(4): 361-375.

[36] Mougeot J. (2005). The World Local Organizations; the Social, Political and Environmental Dimensions of Urban Agriculture. Agropolis; IDRC Publishers.

[37] Mugenda O. and Mugenda. G. (2003). Research Method-Qualitative and Qualitative. Nairobi: Pauline Publication Africa.

[38] Nikkhah, A. N. and Redzuan, M. B. (2010). The Role of NGO in Promoting Empowerment for Sustainable Development. Pp 85-92.

[39] Nwagha - Ngeri, G (1995). An Inventory of NGOs in Nigeria Kuduna; Arewa Press

[40] Oakley, P. (1991). Projects with people: The Practice of Participation in Rural Development. International Labor Office: Geneva. Switzerland.

[41] Ogula, P. A. (2005). Research Methods. Nairobi: CUEA Publications.

[42] Okeke, B. A. (2000). "Barriers in Effective Family/ Community Participation in the Education of Exceptio nal Nigerians". www.isec2000.org.uk accessed 13September 2012.

[43] Orodho, J. A (2005). Elements of Education and social science research methods. Nairobi: Masola.

[44] Osodo, P. \& Matsvai, S. (1997). Partners or contractors? The relationship between official agencies and NGOs-Kenya and Zimbabwe. (Occasional Paper Number 16). International NGO Training and Research Centre (INTRAC).

[45] Oxfam. (2001). “Gender and Development.” London: OXFAM.

[46] Pretty, J. (1995). Participation Learning and Action: A Trainers Guide. London: IIED.

[47] Republic of Kenya NGO Coordination Board (2013). NGOs online database search.

[48] Riddell, R. (2007). Does foreign aid really work? Oxford: Oxford University Press.

[49] Rooy, A. V. (1997). Civil society and the aid industry. London: Earthscan.

[50] Rose-Ackerman, S. (1996). Altruism, Non-profits, and economic Theory. Journal of Literature re: (34):701-728.

[51] Rose, P. (2011). Strategies for engagement: government and national non government providers in South Asia. Public Administration and Development 31:294-305.

Economic

] Salamon, L. and Anheiser, H. (1999). "The Third Route; Subsidiary third-party government and donors' relationships in Income-generating projects in Bangladesh. World Development: Vol.19, No.10 (1993) pp.1367-1380.

[53] Sengsourivong, K. (2006). The Impact of Micro Finance on Household Welfare: Case Study of a Savings Group in Lao PDR.17. 
[54] Schmidt, A.P. (2002). Thesaurus and Glossary of Early Warning and Conflict Prevention Terms (Abridged Version), FEWER - Forum on Early Warning and Early Response.

[55] Singer, P. (2009). How Can You Tell Which Charities Do It Best?" in The Life You Can Save, pp. 82125. New York: Random House.

[56] Streeten P (1997). Non-governmental Organizations and Development. Annals of the American Academy of Political and Social Science, 554: 193-210.

[57] Thomas, A. (1992). NGOs and the limits to empowerment. In Wuyts, M., Mackintosh, M. and Hewitt. T. (Eds) Development action and public policy. Oxford: Oxford University Press.

[58] Todaro, M. \& Smith, S. (2008). Economic Development. 10th Edition: Addison Wesley.

[59] Tunrago, P. (2009). Non-governmental Organizations and Development. Annals of the: American Academy of Political and Social Science, 554: 193-210.

[60] United Nations (2008). Darfur Humanitarian Profile No 33, Office of UN Deputy Special Representative of the UN Secretary-General for Sudan UN Resident and Humanitarian coordinator.

[61] Vilain, M. (2002). Nonprofit-Management: Current Challenges for Personnel Management in German Welfare Organizations. In: ISTR (Hrsg.): Transforming Civil Society, Citizenship and Governance: The 3rd Sector in an Era of Global (Dis) Order. Conference Working Papers, Volume III, Cape Town Conference, July 7-10.

[62] Weisbrod, B. (1974). Toward a Theory of the Voluntary Non-Profit Sector in a Three- Sector Economy. In Altruism, Morality and Economic Theory. Phelps, E.S. (ed). New York: Russel Sage.

[63] Wolvaardt, G. Van Niftrik, J., Beira, B., Mapham, W. \& Stander, T. (2008). The Role of Private and Other Non-Governmental Organisations in Primary Health Care.

[64] World Bank, (2007). Reaching the Poor with Health Services in Cambodia: Contracting Health Care Services for the Rural Poor: Washington DC.

[65] Young, D.R. (2000). Alternative Models of Government- Non-Profit Relation: Theoretical and Empirical Perspectives. Nonprofit and Voluntary Sector: Quarterly, (29):149-172.

[66] Young, K. (1993). Planning Development with Women, Making a world difference:Planning from the Gender Perspective London: Macmillan.

[67] Zaidi, S.A (1999). NGO Failure and the Need to Bring Back the State. Journal of International Development, 11: 259- 271.

Citation: Timothy Chemweno. "Influence of Development Partnership on State-Ingo Relations in Kenya" International Journal of Sports and Physical Education (IJSPE), vol 6, no. 1, 2020, pp. 16-36. doi: http://dx.doi.org/10.20431/2454-6380.0601003.

Copyright: (C) 2020 Authors. This is an open-access article distributed under the terms of the Creative Commons Attribution License, which permits unrestricted use, distribution, and reproduction in any medium, provided the original author and source are credited. 